\title{
STUDI SIFAT MAGNET DAN SPEKTROSKOPI SINAR TAMPAK PADA DARAH HIJAMAH
}

\author{
RESI RosAnTI $^{1 *}$, DEDE SUHENDAR ${ }^{1}$, EKo PrabOWO HADISANTOSO ${ }^{1}$, DAN CITRA FITRIANI KUSMAN ${ }^{1}$ \\ ${ }^{1}$ Jurusan Kimia, Fakultas Sains dan Teknologi, UIN Sunan Gunung Djati Bandung, \\ Jl. A. H. Nasution No. 105 Cibiru Kota Bandung \\ *alamat email korespondensi: rosantiresi@gmail.com
}

\begin{tabular}{|c|c|}
\hline Informasi Artikel & Abstrak/Abstract \\
\hline $\begin{array}{l}\text { Riwayat Naskah : } \\
\text { Diterima pada } 4 \text { Mei } \\
2018 \\
\text { Diterima setelah } \\
\text { direvisi pada } 29 \text { Mei } \\
2018 \\
\text { Diterbitkan pada } 28 \\
\text { Juni } 2018\end{array}$ & $\begin{array}{l}\text { Besi merupakan mikromineral yang paling banyak dalam tubuh makhluk hidup yang memiliki } \\
\text { peranan penting dalam reaksi biokimia, yaitu pada proses transfer oksigen. Telah dilakukan } \\
\text { pengkajian kadar dan kimiawi besi dalam darah hijamah berdasarkan waktu sampling, jenis } \\
\text { kelamin dan objek usia yang berbeda dengan menggunakan neraca kerentanan magnet } \\
\text { (Magnetic Susceptibility Balance, MSB) dan pola spektrum sinar tampak. Dilakukan pula } \\
\text { analisis kuantitatif dengan menggunakan pektroskopi serapan atom (SSA) untuk menegaskan } \\
\text { hasil yang diperoleh dari penentuan sifat magnet dan spektrum sinar tampak. Sifat magnet } \\
\text { yang dianalisis menggunakan neraca kerentanan magnet (MSB) terhadap hasil sampling } \\
\text { tanggal } 19 \text { bulan Hijriyah, jenis kelamin laki-laki, dan objek sampel usia } 40-50 \text { tahun kurang } \\
\text { paramagnetik daripada waktu sampling tanggal } 4 \text { bulan Hijriyah, jenis kelamin perempuan, } \\
\text { dan objek usia } 20-30 \text { tahun. Hasil pengamatan spektroskopi sinar tampak menghasilkan } \\
\text { puncak pada panjang gelombang } 400-415 \mathrm{~nm} \text { yang mengindikasikan keberadaan kompleks } \\
\text { besi-porfirin. Analisis menggunakan spektroskopi serapan atom (SSA) menghasilkan } \\
\text { perubahan kadar besi pada sampling tanggal } 19 \text { bulan Hijriyah, pada jenis kelamin laki-laki, } \\
\text { dan pada objek sampel usia } 40-50 \text { lebih banyak daripada waktu sampling tanggal } 4 \text { bulan } \\
\text { Hijriyah, pada jenis kelamin perempuan, dan objek usia } 20-30 \text { tahun. }\end{array}$ \\
\hline $\begin{array}{l}\text { Keywords: } \\
\text { Iron; blood of } \\
\text { hijamah; porphyrin; } \\
\text { magnetic } \\
\text { characteristic; } \\
\text { spectroscopy. }\end{array}$ & $\begin{array}{l}\text { Iron is the most widely micromineral in the body of human which has an important role in } \\
\text { biochemical reactions, is the process of oxygen transfer. Studies had been carried out of } \\
\text { determine the chemical content of iron in the blood of hijamah in the sampling time, the } \\
\text { gender, and the different age using magnetic susceptibility balance (MSB) and patterns of the } \\
\text { visible spectrum. Also conducted quantitative analysis using atomic absorption spectroscopy } \\
\text { (AAS) to affirm the result obtained from determine of the magnetic characteristic and the } \\
\text { visible spectrum. Magnetic characteristic analyzed by magnetic susceptibility balance (MSB) } \\
\text { in the sampling at } 19^{\text {th }} \text { Hijriyah, in male, and the age } 40-50 \text { years is less paramagnetic than } \\
\text { the sampling time at } 4^{\text {th }} \text { Hijriyah, in female, and the age } 20-30 \text { years. The result of visible } \\
\text { spectroscopy produces a peak at a wavelength of } 400-415 \mathrm{~nm} \text { that indicating the presence } \\
\text { complex of Iron-Porphyrin. In analyzing using atomic absorption spectroscopy (AAS) show } \\
\text { that the iron concentration in the sampling at } 19^{\text {th }} \text { Hijriyah, in male, and the age } 40-50 \text { years } \\
\text { is higher than the sampling time at } 4^{\text {th }} \text { Hijriyah, in female, and the age } 20-30 \text { years. }\end{array}$ \\
\hline
\end{tabular}

\section{PENDAHULUAN}

Besi memiliki peranan penting dalam proses berbagai reaksi biokimia, seperti pada proses transfer oksigen. Besi ini diperlukan dalam proses pembentukan sel darah merah yang mengandung senyawa kimia bernama hemoglobin untuk membawa oksigen dari paruparu dan mengantarkannya ke seluruh tubuh. Dalam tubuh zat besi terkonjugasi menjadi dua, bentuk aktif berupa ferro $\left(\mathrm{Fe}^{2+}\right)$ dan bentuk inaktif berupa ferri $\left(\mathrm{Fe}^{3+}\right)$. Di dalam darah ion besi aktif $\mathrm{Fe}^{2+}$ berikatan dengan heme membentuk molekul hemoglobin [1]. Kandungan besi total dalam tubuh sekitar 4-5 g [2], sedangkan dalam keadaan normal kandungan besi dalam darah adalah 250-450 $\mu \mathrm{g} / \mathrm{dL}$. Kekurangan zat besi pada menu makanan sehari-hari dapat menyebabkan anemia. Jika kadarnya berlebih dapat meracuni tubuh, seperti menyebabkan timbulnya radikal bebas dan penyebab kerusakan sel $\beta$ pankreas [3].

Berkaitan dengan hal tersebut, terdapat pengobatan sunah Rasul yaitu teknik pengobatan bekam atau hijamah yang merupakan suatu proses membuang darah kotor yang berbahaya dalam tubuh melalui permukaan kulit [4]. Sebagaimana sabda Rasulallah: "sebaik-baik obat yang kamu gunakan untuk berobat adalah berbekam atau obat yang paling baik bagimu adalah berbekam." (HR. Muslim)

Selain itu terdapat waktu terbaik untuk melakukan hijamah seperti yang disebutkan 
dalam hadist riwayat Abu Dawud, Bercerita kepada kami Abi Taubah ar-Rabi bin Nafi bercerita kepada kami Sai'id bin Abdurrahman al-Jamhiyu dari Sahil, dari bapaknya, dari Abi Hurairah berkata, Rasulallah SAW bersabda: "Barangsiapa berbekam pada tanggal tujuh belas, sembilan belas dan duapuluh satu, maka ia akan menyembuhkan segala macam penyakit." Namun, selain tanggal yang dianjurkan diatas hijamah (bekam) kapan saja bisa dilakukan [5]. Pada tanggal sunah, cairan-cairan seperti darah di dalam tubuh sedang bergejolak mengikuti gravitasi di bumi, sehingga racun-racun atau logam-logam yang berlebihan dalam tubuh ikt bergejolak. Jadi, dengan hijamah racun-racun tersebut dapat keluar melalui darah [6].

Berdasarkan penelitian, hijamah efektif dalam mempengaruhi penurunan tekanan darah pada penderita hipertensi [7], mencegah penyakit kardiovaskuler, hipertensi, ateroskerosis, jantung koroner dan talasemia [8]. Dari penelitian yang dilakukan Kusman (2015), diperoleh hasil bahwa kadar besi dalam darah hijamah pada tanggal 19 hijriyah lebih besar daripada darah hijamah yang diambil pada tanggal 4 hijriyah dengan asumsi bahwa pada tanggal 19 hijriyah darah sedang bergejolak (sedang banyak) dan kapasitas ikatan zat besi dalam darah hijamah cukup tinggi sehingga logam besi berlebih dalam tubuh dikeluarkan melalui hijamah ini. Selain itu diperoleh hasil komponen kimiawi pada sampel darah hijamah adalah kompleks besi-porfirin serta bersifat paramagnetik [9].

Penelitian mengenai hijamah ini dilakukan kembali agar memberikan informasi lanjutan tentang keberadaan besi dalam darah hijamah. Pertama, ditinjau dari sifat magnet darah hijamah yang dianalisis menggunakan Neraca Kerentanan Magnet (MSB). Sifat magnet sendiri dibedakan menjadi dua, paramagnetik dan diamagnetik [10]. Kompleks dengan medan ligan lemah menghasilkan pemisahan orbital $d$ yang tidak terlalu besar, sehingga setelah elektron memenuhi orbital $d$ energi rendah elektron berikutnya akan mengisi orbital $d$ energi tinggi, sehingga elektron cenderung tidak berpasangan. Keadaan ini menimbulkan spin tinggi yang menyebabkan sifat paramagnetik. Kompleks dengan medan ligan kuat menghasilkan pemisahan orbital $d$ yang cukup besar, sehingga elektron cenderung berpasangan. Keadaan ini menimbulkan spin rendah yang menyebabkan sifat diamagnetik [11].

Kedua, dilakukan analisis kimiawi darah hijamah menggunakan spektroskopi sinar tampak pada panjang gelombang 200-80 $\mathrm{nm}$. Diperoleh absorbansi (A) sebagai persentase jumlah cahaya yang diteruskan atau diserap yang terukur oleh detektor [12]. Untuk memperjelas hasil analisis sifat magnet dan spektroskopi sinar tampak dilakukan analisis kadar besi dalam darah hijamah menggunakan spektroskopi serapan atom (SSA) pada panjang gelombang $372 \mathrm{~nm}$ ).

\section{EKSPERIMEN}

\section{Material}

Bahan-bahan yang digunakan dalam penelitian ini adalah $\mathrm{HNO}_{3}$ pekat (p.a, Merck ${ }^{\circledR}$ ), akua dm, akuabides, $\mathrm{H}_{2} \mathrm{O}_{2}\left(20 \%\right.$, Merck $\left.{ }^{\circledR}\right)$, alkohol $\left(70 \%\right.$, Merck $\left.^{\circledR}\right)$, dan aluminium foil).

\section{Instrumentasi}

Instrumentasi yang digunakan dalam penelitian ini adalah neraca kerentanan magnet (Magnetic Susceptibility Balance, Sherwood Scientific), untuk mengetahui kimiawi besi dalam darah hijamah digunakan spektroskopi UV-Vis (Cary,60), serta untuk pengujian kadar besi dalam darah hijamah digunakan spektroskopi serapan atom (200 Series AA).

\section{Prosedur}

\section{Sampling Darah}

Sampling darah hijamah dilakukan sebanyak dua tahap, yaitu sampling pada tanggal 19 (sebagai tanggal sunah hijamah) dan tanggal 4 di bulan Hijriyah selama 3 bulan berturut-turut. Objek pengambilan sampel darah hijamah dibuat bervariasi, yaitu pada laki-laki dan perempuan yang berusia 20-30 tahun dan berusia 40-50 tahun. Sampel darah hijamah disimpan dalam tabung vacutainer dalam lemari pendingin.

\section{Preparasi Sampel Penentuan Sifat Magnet dalam Darah Hijamah}

Sampel darah hijamah sebanyak $3 \mathrm{~mL}$ dimasukkan ke dalam gelas kimia $100 \mathrm{~mL}$ dan dipanaskan pada $100-105{ }^{\circ} \mathrm{C}$ selama \pm 30 menit. Sampel yang telah dipanaskan, didiamkan di desikator lalu serbuk kering ini digerus hingga halus. Selanjutnya diuji sifat magnetnya menggunakan neraca kerentanan magnet (MSB).

\section{Preparasi Sampel Penentuan Kimiawi Darah Hijamah}

Sampel darah hijamah diencerkan terlebih dahulu, yaitu sebanyak $100 \mu \mathrm{L}$ sampel darah 
hijamah diencerkan ke dalam $60 \mathrm{~mL}$ akuabides di dalam gelas kimia $100 \mathrm{~mL}$. Kemudian hasil pengenceran diambil sebanyak 2-3 $\mathrm{mL}$ dan dimasukkan ke dalam kuvet. Larutan sampel dianalisis menggunakan spektrofotometer UVVis pada panjang gelombang $200-800 \mathrm{~nm}$.

\section{Pembuatan Larutan Standar Fe}

Prosedur pembuatan larutan Standar $\mathrm{Fe}$ yang digunakan mengacu pada referensi [9]. Dibuat larutan induk $\mathrm{Fe}$ dengan mengencerkan larutan induk 1000 ppm dalam larutan $\mathrm{HNO}_{3} 0,5$ $\mathrm{mol} / \mathrm{L}$. lalu dibuat seri larutan standar $0,5,10$, 15, 20, dan 25 ppm dengan diencerkan kedalam labu ukur $50 \mathrm{~mL}$ dengan akua dm hingga tanda batas, dan dihomogenkan. Selanjutnya dibuat kurva kalibrasi, kurva kalibrasi yang terbentuk digunakan untuk perhitungan kadar pada pengukuran sampel.

\section{Preparasi Sampel Penentuan Kadar Besi dalam Darah Hijamah}

Sampel darah hijamah diambil sebanyak 5 g kemudian ditambahkan dengan $5 \mathrm{~mL} \mathrm{HNO}_{3}$ pekat selanjutnya dipanaskan pada $110^{\circ} \mathrm{C}$ selama 1-2 jam dan ditambahkan larutan $\mathrm{H}_{2} \mathrm{O}_{2}$ tetes demi tetes hingga sisa larutan sebanyak $1 \mathrm{~mL}$. Larutan diecerkan hingga $25 \mathrm{~mL}$ dengan menggunakan akua dm dan diencerkan kembali hingga 10x ke dalam labu ukur $250 \mathrm{~mL}$. Kadar besi dalam darah hijamah diukur menggunakan spektroskopi serapan atom (SSA) menggunakan nyala dari udara-asetilena dengan panjang gelombang yang digunakan adalah $372 \mathrm{~nm}$.

\section{HASIL DAN PEMBAHASAN}

\section{Analisis Sifat Magnet pada Darah Hijamah}

Proses Sampel darah hijamah yang telah dipanaskan dan menjadi serbuk, dilakukan pengujian dengan neraca kerentanan magnet untuk mengetahui sifat magnetnya. Pengujian dilakukan dengan menimbang berat antara 0,10 $0,15 \mathrm{~g}$ dan mengukur tinggi sampel dalam tabung antara 2,50- 2,55 cm. Kemudian sampel diukur dengan neraca kerentanan magnet dan diperoleh hasil pembacaannya.Pembacaan pada neraca kerentanan magnet jika bernilai positif maka sampel yang dianalisis bersifat paramagnetik dan jika bernilai negatif bersifat diamagnetik. Hasil analisis menunjukkan bahwa untuk semua sampel darah hijamah bersifat paramagnetik, dengan diperoleh hasil pembacaan yang berilai positif baik pada tanggal 19 ataupun tanggal 4 pada bulan Hijriyah.

Diperoleh hasil sifat paramagnetik pada LKM dan PRM di bulan Januari (Rabiul Akhir) lebih besar daripada LKT dan PRT. Terdapat pola yang sama dalam hasil analisis sampel darah hijamah yang diambil tanggal 19 bulan Hijriyah, pola cenderung turun. Artinya sifat paramagnetiknya cenderung berkurang. Hal ini ditunjukkan pada Gambar 1.

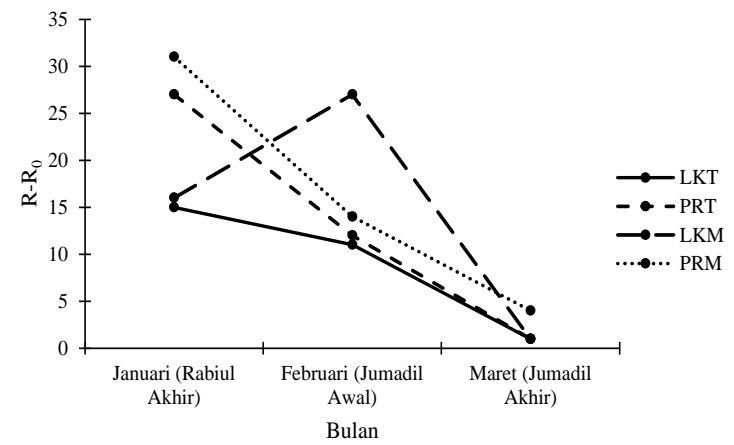

LKT= Laki-laki 40-50 tahun, PRT= Perempuan 40-50 tahun, $\mathrm{LKM}=$ Laki-laki 20-30 tahun, PRM= Perempuan 20-30 tahun

Gambar 1. Pembacaan R-R 0 pada neraca kerentanan magnet darah hijamah pada tanggal 19 bulan Hijriyah.

Berdasarkan Gambar 2, diperoleh hasil sifat paramagnetik pada LKM dan PRM di bulan Februari (Jumadil Awal) lebih besar daripada LKT dan PRT. Terdapat 2 pola dalam hasil analisis sampel darah hijamah yang diambil tanggal 4 bulan Hijriyah, pola naik dan turun sifat magnetnya. Untuk LKT dan PRT memiliki pola naik yang artinya sifat paramagnetiknya cenderung bertambah, sedangkan pada LKM dan PRM memiliki pola turun yang artinya sifat paramagnetiknya berkurang.

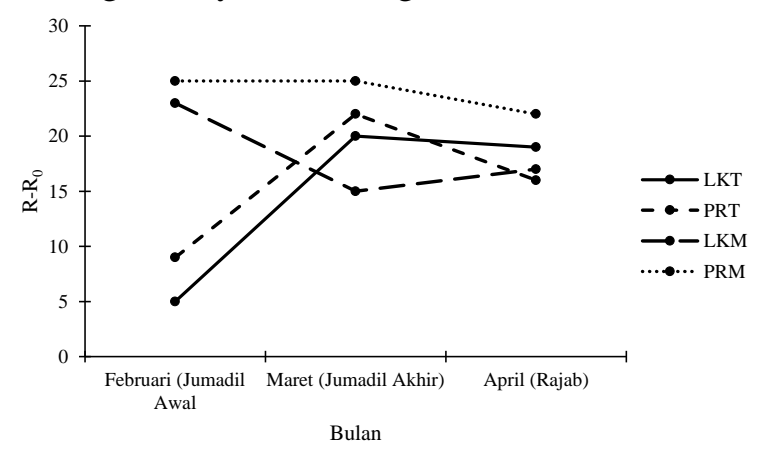

LKT= Laki-laki 40-50 tahun, PRT= Perempuan 40-50 tahun, LKM= Laki-laki 20-30 tahun, PRM= Perempuan 20-30 tahun

Gambar 2 Pembacaan R-R 0 pada neraca kerentanan magnet darah hijamah pada tanggal 4 bulan Hijriyah

Sifat paramagnetik yang ditunjukkan dalam hasil analisis pada neraca kerentanan magnet mengindikasikan adanya keberadaan 
kimiawi besi dalam darah hijamah yang merupakan logam yang terdapat dalam darah. Kecenderungan sifat paramagnetik yang ditimbulkan dari adanya besi pada darah hijamah dapat dipengaruhi oleh beberapa hal, seperti faktor makanan. Zat besi dalam tubuh diperoleh dari asupan makanan yang dikonsumsi yang bersumber dari makanan seperti daging, ikan, dan sumber makanan nabati seperti sayuran atau kacang-kacangan.

Namun, kecenderungan sifat magnet pada darah pun bisa disebabkan hal lainnya karena dalam darah sendiri tidak hanya besi saja yang dominan mempengaruhi kemagnetan namun juga komponen-komponen zat yang ada dalam darah pada umumnya seperti karbohidrat (glukosa, glikogen), lipid (kolesterol, asam-asam lemak), protein (plasma, serum, albumin), vitamin, senyawa nitrogen nonprotein (asam urat), dan elektrolit baik kation maupun anion. Dalam keadaan ini, besi hanya berinteraksi sederhana dengan gugus porfirin. Kemungkinan terdapat ligan lain yang terikat terhadap besi ataupun kehadiran molekul-molekul lain yang mempengaruhi kekuatan gugus porfirin sebagai ligan. Seperti molekul-molekul dalam darah (karbohidrat, protein, lemak, dll) yang memiliki rasio massa lebih tinggi daripada komponen utama yaitu besi-porfirin yang menyebabkan kekuatan gugus porfirin berkurang.

Senyawa-senyawa tersebut juga mempengaruhi kemagnetan pada darah, seperti bentuk hemoglobin yaitu oksihemoglobin dan deoksihemoglobin. Di mana oksihemoglobin bersifat diamagnetik sedangkan deoksihemoglobin bersifat paramagnetik [13]. Keberadaan senyawa-senyawa tersebut ditunjukkan dengan adanya puncak pada panjang gelombang tertentu pada hasil analisis menggunakan spektroskopi UV-Vis. Hal tersebut diatas bisa mempengaruhi keadaan ada atau tidaknya pasangan elektron bebas pada kompleks besi.

Kompleks besi yang memiliki pasangan elektron bebas akan bersifat paramagnetik sedangkan kompleks besi yang tidak memiliki pasangan elektron bebas memberikan sifat diamagnetik. Sifat paramagnetik yang cenderung berkurang ini menandakan keadaan spin besi rendah, yang dipengaruhi oleh medan ligan kuat. Medan ligan kuat menyebabkan perbedaan tingkat energi pemisahan orbital $d$ yang lebih besar, dimana senyawa kompleks yang memiliki medan ligan kuat tidak akan menempatkan elektron-elektronnya ke orbital yang berenergi tinggi, sehingga elektron cenderung berpasangan.

\section{Analisis Kimiawi Darah Hijamah}

Pada sampel darah hijamah dilakukan pengujian kualitatif menggunakan spektrofotometer UV-Vis, dengan rentang panjang gelombang yang digunakan dalam pengukuran antara 200-800 nm. Diperoleh hasil spektrum-spektrum yang hampir sama pada semua sampel darah hijamah, di mana berdasarkan hasil analisis komponen kimiawi darah yaitu DNA dan RNA sebagai faktor informasi genetik yang ditunjukkan dengan munculnya puncak pada panjang gelombang pada $260 \mathrm{~nm}$. Protein yang terdapat pada plasma darah untuk mengangkut dan mengedarkan sari-sari makanan ke seluruh tubuh ditunjukkan dengan munculnya puncak pada panjang gelombang 280 $\mathrm{nm}$, enzim yang juga terdapat pada plasma darah ditunjukkan dengan munculnya puncak pada panjang gelombang $340 \mathrm{~nm}$. Kompleks porfirin yaitu besi-porfirin yang ditunjukkan dengan munculnya puncak pada 400-415 nm, serta puncak yang mucul pada $575 \mathrm{~nm}$ sebagai oksihemoglobin, dan pada $550 \mathrm{~nm}$ sebagai deoksihemoglobin.

Dalam hal ini, terdapat komponen kimiawi besi dominan ditunjukkan oleh puncak dari panjang gelombang kompleks porfirin (berwarna merah), sebagai dominasi warna darah dari eritrosit. Puncak spektrum yang terlihat jelas berada pada serapan panjang gelombang antara $400-415 \mathrm{~nm}$, yaitu pada panjang gelombang dari kompleks porfirin.

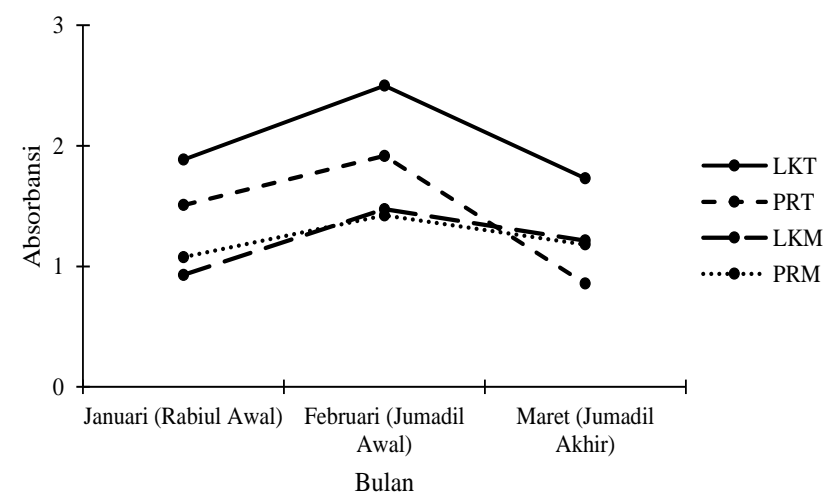

LKT = Laki-laki 40-50 tahun, PRT= Perempuan 40-50 tahun, $\quad \mathrm{LKM}=$ Laki-laki 20-30 tahun, $\mathrm{PRM}=$ Perempuan 20-30 tahun

Gambar 3. Perbedaan absorbansi daerah kompleks porfirin pada darah hijamah tanggal 19 bulan Hijriyah dengan spektrofotometer UV-Vis

Struktur porfirin mempunyai ikatan rangkap terkonjugasi yang memungkinkan terjadinya proses serapan gelombang elektromagnetik yang mengeksitasi elektronelektron dari tingkat dasar ke tingkat eksitasi. 
Selain itu, ligan porfirin memiliki celah energi kecil, daya serap besar sehingga senyawa ini berpotensi menghasilkan spektrum sinar tampak [14]. Besarnya kompleks porfirin (dapat dikatakan konsentrasi atau jumlah) menyebabkan panjang gelombang serapan dari kompleks porfirin berubah. Konsentrasi kompleks porfirin yang tinggi menyebabkan ligan memberikan substitusi besar pada kompleksnya, sehingga menghasilkan energi yang tinggi dengan menyerap panjang gelombang yang lebih pendek, perbedaan absorbansi yang menunjukkan kadar kompleks porfirin yang ditunjukkan pada Gambar 3 dan Gambar 4.

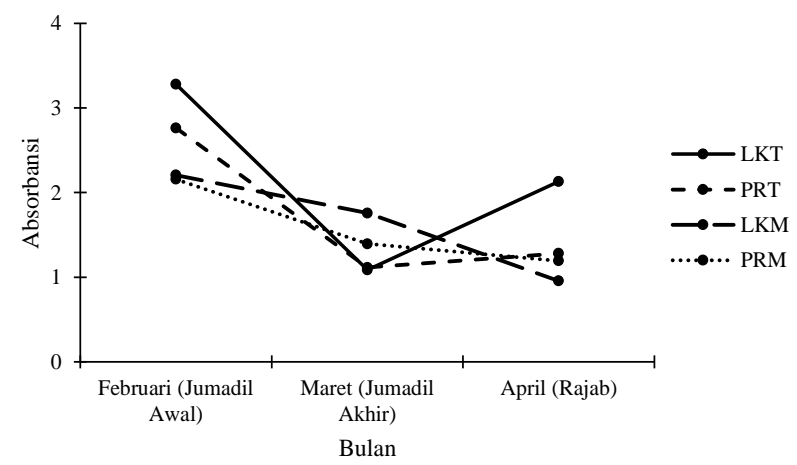

LKT= Laki-laki 40-50 tahun, PRT= Perempuan 40-50 tahun, LKM= Laki-laki 20-30 tahun, PRM= Perempuan 20-30 tahun

Gambar 4. Perbedaan absorbansi daerah kompleks porfirin pada darah hijamah tanggal 4 bulan Hijriyah dengan spektrofotometer UV-Vis.

Berdasarkan Gambar 3 dan Gambar 4, absorbansi dari pengukuran dengan UV-Vis membenarkan pernyataan bahwa absorbansi kompleks porfirin akan mempengaruhi konsentrasi atau kadar kompleks porfirin. Pengaruh pelebaran pemisahan orbital $d$, sebagai akibat terdapatnya tambahan ligan lain yang bisa terikat dengan besi dapat mempengaruhi kekuatan gugus porfirin sebagai ligan. Dalam hal ini, senyawa kompleks porfirin (berwarna) bergantung pada nilai perbedaan tingkat energi, semakin besar nilai perbedaan tingkat energinya maka cahaya yang memiliki energi rendah akan diserap, dan akan bergeser pada panjang gelombang yang lebih tinggi. Dari hasil penelitian yang diperoleh pada sampel darah hijamah di tanggal 19 bulan Hijriyah bahwa absorbansi meningkat pada panjang gelombang kompleks porfirin yang sedikit bergeser ke panjang gelombang lebih pendek, yang berarti nilai perbedaan tingkat energinya rendah maka cahaya yang memiliki energi tinggi akan diserap. Dengan kata lain, kekuatan dari gugus porfirin sebagai ligan menjadi berkurang.
Berkurangnya kekuatan ligan porfirin, dimungkinkan besi bergabung dengan lgan-ligan lain yang mampu untuk dapat mengikat besi misalnya (alanin, aldosteron, asam-asam amino, keton, dan lain-lain). Meskipun ligan-ligan tersebut dalam jumlah yang sedikit sehingga tidak seluruhnya terbaca pada hasil spektrum UV-Vis, namun berpengaruh pada besarnya absorbansi kompleks porfirin karena jumlah porfirin dominan dibandingkan dengan liganligan lain yang dapat mengikat besi.

\section{Analisis Kadar Besi pada Darah Hijamah}

Analisis kuantitatif menggunakan spektroskopi serapan atom (SSA) digunakan untuk mengetahui kadar besi dalam darah hijamah. Pengukuran dalam menentukan kadar besi dilakukan pada panjang gelombang $372 \mathrm{~nm}$. Pada spektroskopi serapan atom (SSA) kurva kalibrasi dibuat untuk memperoleh hubungan antara konsentrasi dan absorbansi. Larutan standar yang digunakan adalah larutan $\mathrm{Fe}\left(\mathrm{NO}_{3}\right)_{3} .9 \mathrm{H}_{2} \mathrm{O}$. konsentrasi yang digunakan dalam pengukuran kurva kalibrasi ini berjumlah enam variasi konsentrasi, yaitu $0,5,10,15,20$, dan 25 ppm. Kemudian dibuat kurva kalibrasi konsentrasi standar $\mathrm{Fe}$ terhadap absorbansi, seperti yang ditunjukkan pada Gambar 5.

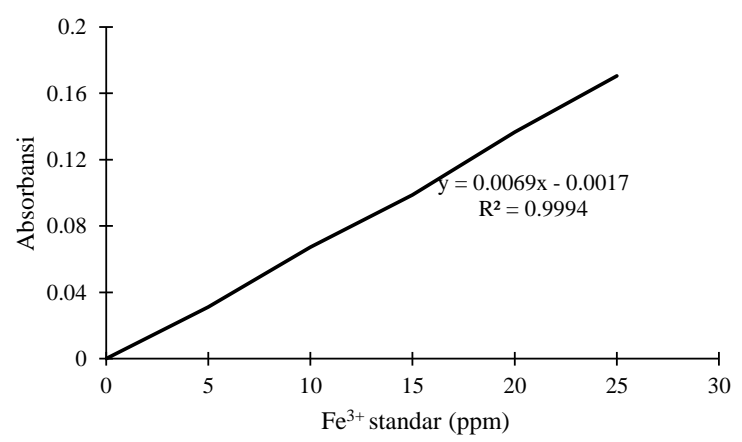

Gambar 5. Kurva kalibrasi besi $\left(\mathrm{Fe}^{3+}\right)$ standar

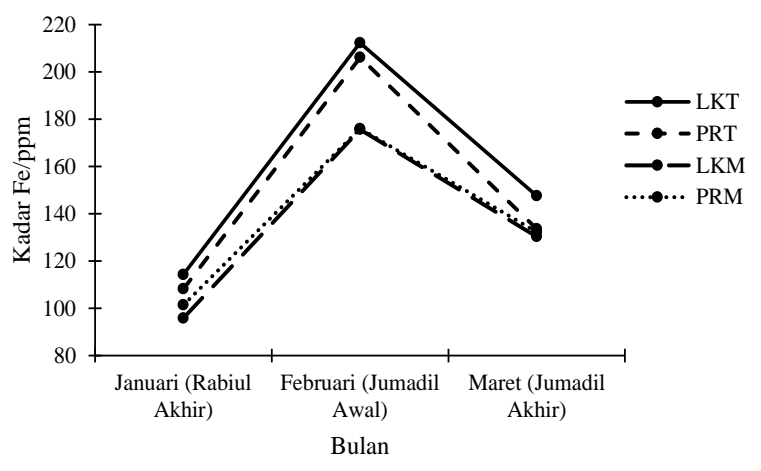

LKT= Laki-laki 40-50 tahun, PRT= Perempuan 40-50 tahun, $\mathrm{LKM}=$ Laki-laki 20-30 tahun, $\mathrm{PRM}=$ Perempuan 20-30 tahun

Gambar 6. Diag perbandingan kadar Fe pada tanggal 19 bulan Hijriyah 
Dengan kurva yang berbentuk linier dengan nilai linearitas 0,9994 (mendekati satu) ini, dapat disimpulkan bahwa standar dapat digunakan sebagai kurva kalibrasi.

Dilihat dari waktu pengambilan sampel darah hijamah, kadar Fe dalam darah hijamah memiliki besar yang berbeda-beda. Pada Gambar 6, diperoleh hasil perubahan kadar besi di punggung pada objek usia 40-50 tahun lebih banyak daripada objek usia 20-30 tahun. Kadar besi LKT lebih banyak daripada PRT sedangkan kadar besi LKM lebih banyak daripada PRM.

Berdasarkan Gambar 7, diperoleh hasil perubahan kadar besi di punggung pada laki-laki lebih banyak daripada perempuan. Kadar besi LKT lebih banyak daripada LKM sedangkan kadar besi pada PRM lebih banyak daripada PRT.

Secara keseluruhan, perubahan kadar besi pada darah hijamah yang diambil tanggal 19 bulan Hijriyah lebih besar daripada tanggal 4 bulan Hijriyah. Ditinjau dari jenis kelamin, pada objek sampel darah hijamah perempuan perubahan kadar besi cenderung lebih sedikit dibandingkan dengan laki-laki sedangkan jika ditinjau dari usia, perubahan kadar besi pada objek sampel usia 20-30 tahun lebih sedikit daripada usia 40-50 tahun. kadar besi dalam darah yang diambil secara normal baik pada lakilaki maupun perempuan dewasa berada pada kisaran 65-165 $\mu \mathrm{g} / \mathrm{dL}$ atau sama dengan 0,651,65 ppm [15]. Hal tersebut menunjukkan bahwa kadar besi yang diambil pada hijamah lebih tinggi daripada kadar besi dalam darah normal yang diambil melalui vena.

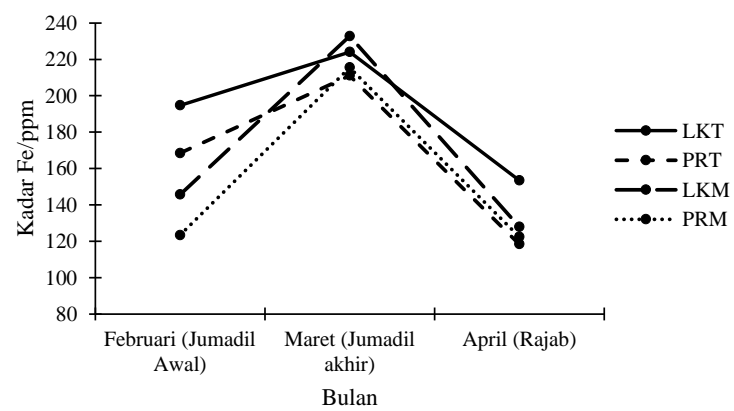

LKT $=$ Laki-laki 40-50 tahun, PRT= Perempuan 40-50 tahun, $\quad \mathrm{LKM}=$ Laki-laki 20-30 tahun, $\mathrm{PRM}=$ Perempuan 20-30 tahun

Gambar 7. Diag perbandingan kadar Fe pada tanggal 4 bulan Hijriyah

Secara keseluruhan, perubahan kadar besi pada darah hijamah yang diambil tanggal 19 bulan Hijriyah lebih besar daripada tanggal 4 bulan Hijriyah. Ditinjau dari jenis kelamin, pada objek sampel darah hijamah perempuan perubahan kadar besi cenderung lebih sedikit dibandingkan dengan laki-laki sedangkan jika ditinjau dari usia, perubahan kadar besi pada objek sampel usia 20-30 tahun lebih sedikit daripada usia 40-50 tahun. kadar besi dalam darah yang diambil secara normal baik pada lakilaki maupun perempuan dewasa berada pada kisaran 65-165 $\mu \mathrm{g} / \mathrm{dL}$ atau sama dengan 0,651,65 ppm [15]. Hal tersebut menunjukkan bahwa kadar besi yang diambil pada hijamah lebih tinggi daripada kadar besi dalam darah normal yang diambil melalui vena.

Sampel LKT memiliki kadar besi yang lebih tinggi daripada PRT, hal tersebut dapat diakibatkan keadaan dari PRT yang premenopause yaitu keadaan fisiologis pada wanita yang berusia menjelang 40 tahun keatas dan telah memasuki proses penuaan [16]. Pada perempuan pre-menopause ini, jumlah total zat besinya lebih rendah dibandingkan laki-laki. Perbedaan kadar besi lainnya dapat diakibatkan oleh tekanan darah dari masing-masing sampel objek. Secara langsung, antara besi dan tekanan darah memang tidak berhubungan. Namun, tekanan darah akan berhubungan dengan jumlah sel darah merah dimana mempengaruhi kekentalan darah. Tekanan darah yang tinggi memungkinkan darah menjadi lebih kental sehingga kadar besi dalam darahnya pun dimungkinkan akan lebih banyak.

Darah yang dikeluarkan pada hijamah di punggung merupakan darah yang mengandung racun atau darah statis yang menyumbat peredaran darah, mengakibatkan sistem peredaran darah dalam tubuh tidak berjalan sebagaimana adanya, sehingga menyebabkan terganggunya kesehatan seseorang. Keberadaan besi dalam darah hijamah ini, dikeluarkan bukan sebagai besi yang aktif yang menempel pada gugus porfirin dalam hemoglobin melainkan dimungkinkan besi tersebut menempel pada sisi yang bukan porfirin. Besi tersebut merupakan besi yang tidak aktif untuk mengangkut oksigen dalam darah, namun dimungkinkan besi tersebut terambil oleh hijamah bersama senyawa-senyawa lain yang tidak bermanfaat lagi untuk tubuh. Dimungkinkan besi membentuk kompleks dengan ligan-ligan lain yang disukainya dan terikat tanpa memiliki fungsi lain dalam tubuh.

\section{SIMPULAN}

Dari hasil penelitian ini dapat ditarik kesimpulan bahwa sifat magnet yang dianalisis menggunakan neraca kerentanan magnet (MSB) pada waktu sampling tanggal 19 bulan Hijriyah, pada jenis kelamin laki-laki, dan pada objek sampel usia 40-50 tahun kurang paramagnetik daripada waktu sampling tanggal 4 bulan Hijriyah, pada jenis kelamin perempuan, dan objek usia 20-30 tahun. 
Komponen kimiawi darah hijamah yaitu terdapat kompleks besi-porfirin dengan ditunjukkan adanya spektrum pada panjang gelombang kompleks porfirin dengan rentang 400-415 nm. Analisis menggunakan spektroskopi serapan atom (SSA) menghasilkan perubahan kadar besi pada waktu sampling tanggal 19 bulan Hijriyah, pada jenis kelamin laki-laki, dan pada objek sampel usia 40-50 lebih banyak daripada waktu sampling tanggal 4 bulan Hijriyah, pada jenis kelamin perempuan, dan objek usia 20-30 tahun, juga lebih banyak dari kadar besi pada darah yang diambil secara normal.

\section{REFERENSI}

[1] G J Tortora and Bryan Derrickson, Principles of Anatomy and Physiology. USA: John Willey and Sons, Inc, 2009.

[2] A C Guyton and J E Hall, "Blood Cells, Immunity, and Blood Clotting," in Medical Physiology. Philadelphia: Elsevier, Inc, 2006, p. 425.

[3] Muhammad Saifudin Hakim, "Khasiat Bekam Bagi Penderita Diabet," Yogakarta, 2011.

[4] Fatahillah, Keampuhan Bekam (Pencegahan dan Penyembuhan Penyakit Warisan Rasulallah). Jakarta: Qultum Media, 2007.

[5] Oko Haryono, "Hijamah (Bekam) Menurut Hadist Nabi SAW," Skripsi, 2008.

[6] Muhammad Halabi Hamdi, Amin Abdul Fattah, and Amin Kulli, Pedoman Penyembuhan Penyakit Menurut Ajaran Rasulallah SAW. yogyakarta: Absolut, 2005.

[7] Edwin Safrianda, Parjo , and M Ali Maulana, "Efektifitas Terapi Bekam Basah Terhadap Perubahan Tekanan Darah pada Penderita Hipertensi di Rumah Terapi Thibbun Nabawy Pontianak," Skripsi, 2015.
[8] B Refaat, A G El-Shemi, A A Ebid, and M Basalamah, "Islamic Wet Cupping and Risk Factor of Cardiovascular Disease: Effects and Blood Pressure, Metabolic Profile and Serum Electrolytes in Healthy Young Adult Men," Alternative and Integrative Medicine, vol. 1, no. 3, pp. 1-7, 2014.

[9] Citra Fitriani Kusman, "Studi Perbandingan Kadar dan Kimiawi Besi dalam Darah Normal dan Darah Hijamah (Bekam)," Skripsi, 2015.

[10] J Huheey, Ellen A Keiter, and Richard L Keiter, Inorganic Chemistry, 4th ed. New York: Harper Collins College Publisher, 1993.

[11] J D Lee, Concise Inorganic Chemistry, 4th ed. London: Chapman and Hall, 1994.

[12] Harmita , Buku Ajar Analisis Fisiko Kimia. Jakarta: Cipta Kreasi Bersama, 2006.

[13] Maciej Zborowski, Graciela R Ostera, Sarah Milliron, and Jeffrey J Chalmers, "Red Blood Cell Magnetophoresis," Bophysical Journal, vol. 84, pp. 2638-2645, 2003.

[14] Gawan Pamungkas and I Gusti Made Sanjaya, "A Theoritical Studies to Determine Band Gap of Conjugated Porphyrin with Calcium Metal Using Density Functional Theory (DFT)," Journal of Chemistry, vol. 2, 2013.

[15] Adang Muhammad and Osman Sianipar, "Determination of Iron Deficiency in Chronic Disease Anemia by The Role of sTfR-F Index," Indonesian Journal of Clinical Pathology and Medical Laboratory, vol. 12, no. 1, pp. 9-15, 2005.

[16] C W Siah, J Ombiga, L A Adams, J Trinder, and J K Olynyk, Normal iron Metabolism and the Pathophysiology of Iron Overload Disorders.: Clin Biochem Rev, 2006. 